CARRASCOZA, João Anzanello e SANTARELLI, Christiane. Tramas Publicitárias. Narrativas ilustradas de momentos marcantes da publicidade. São Paulo: Ed. Ática. 2009. 127p.

\title{
LITERATURA E PUBLICIDADE: INTERFACES ESTÉTICAS PARA UM CONHECIMENTO SENSÍVEL SOBRE O MUNDO
}

Eneus Trindade ${ }^{1}$

Em 2009, João Anzanello Carrascoza, Professor do Programa de PósGraduação em Comunicação, Mídia e Consumo da ESPM-SP e da Escola de Comunicações e Artes da USP, e Christiane Santarelli, Doutora em Comunicação pela ECA/USP, presenteiam os amantes da publicidade e de suas interfaces estéticas com a obra Tramas Publicitárias. Narrativas ilustradas de momentos marcantes da publicidade, editado pela Ática.

Trata-se de um texto constituído na confluência do campo discursivo, como diria Dominique Maingueneau (1989), entre os gêneros da literatura e da publicidade, que apresenta uma narrativa literária organizada em três contos, permeada por uma narrativa visual publicitária pertinente aos contextos históricos em que a cena discursiva dos contos acontece.

Nas três tramas textuais presentes na obra, publicidade e literatura permitem perceber como o mundo se faz representar no diálogo dos espaços discursivos criados pelos autores, carregados de efeitos intertextuais, possibilitado a verificação daquilo que Antoine Compagnon (2003) descreve, ao constituir sua deontologia dos Estudos Literários, como sendo da ordem das relações entre obra literária, mundo e história e que viabilizam as conexões entre ficção e realidade capazes de mostrar como a literatura e também a publicidade - por que não? - criam condições de acesso a um

\footnotetext{
${ }^{1}$ Professor Adjunto do Departamento de Relações Públicas, Propaganda e Turismo da Escola de Comunicações e Artes da Universidade de São Paulo. Pós-doutorado em Antropologia Visual pela Universidade Aberta de Portugal. Doutor e Mestre em Ciências da Comunicação pela ECA/USP. Graduado em Publicidade e Propaganda pela UFPE. Pesquisador do GESC3 - Grupo de Estudos Semióticos em Comunicação, Cultura e Consumo CNPq/ECA/USP. Editor da Revista Signos do Consumo.
} 
Resenha: Tramas Publicitárias. Narrativas ilustradas de momentos marcantes da publicidade

conhecimento sensível sobre a experiência histórica vivida no seio das culturas do mundo, a exemplo das discussões realizadas pelo belo prefácio que introduz os contos, intitulado Literatura e publicidade - a trama da cultura nas dobras da história, de autoria da Pesquisadora Maria Aparecida Baccega, professora aposentada da Escola de Comunicações e Artes da USP e que hoje integra o time talentoso de profissionais do Programa de Pós-Graduação em Comunicação da ESPM-SP.

No primeiro conto, Um flâneur, os autores constroem um narradorpersonagem que mergulha em um sonho de prazeres do consumo, ao descobrir no exercício de um olhar turista, a Paris do Século XIX, "a máquina de fabulosas novidades" que se faz no texto "girando as engrenagens" dos sonhos da personagem.

O percurso do homem, encantado pelos produtos e pela beleza estética dos cartazes, constitui uma vivência experiencial semelhante ao do Flâneur de Boudelaire, tratado em Walter Benjamin (1985 e 1991) e compatível sobre os questionamentos sociológicos da época retratados no texto, a partir do olhar crítico de Georg Simmel (2004). O sonho do flâneur é interrompido no ápice de sua sinestesia com a Paris do Século XIX, trazendo o viajante à realidade, no despertar de um sonho, para a Paris contemporânea com seus dilemas sociais.

No segundo texto, A memória sangra, a experiência vivida pela personagem Berta, uma judia alemã que deixa narrar seu sofrimento no período da Segunda Guerra Mundial, culmina nas memórias de alguém que, por sorte, sobreviveu ao Holocausto e migrou com seu esposo e filho para o Brasil. A memória do Nazismo e da perseguição aos judeus se manifesta em materiais midiáticos em revistas e de propaganda política, demonstrando pelo sentido da experiência da personagem, aquilo que em Pierre Nora consiste na diferença entre memória e história,

A memória é a vida, sempre carregada por grupos vivos e, nesse sentido, ela está em permanente evolução, aberta à dialética da lembrança e do esquecimento, inconsciente de suas deformações sucessivas, vulnerável a todos os usos e manipulações, susceptível de longas latências e de repentinas revitalizações. A história é a reconstrução sempre problemática e incompleta do que não existe mais. A memória é um fenômeno sempre atual, um elo vivido no eterno presente; a história, uma representação do passado. Porque é afetiva e mágica, a memória não se acomoda a detalhes que a conformam; ela se alimenta de lembranças vagas, telescópicas, globais ou flutuantes, particulares ou simbólicas, sensível a todas as transferências, cenas, censuras ou projeções. A história, porque operação intelectual e laicizante, demanda análise e discurso crítico. A memória instala a lembrança no sagrado, a história a liberta, e a torna sempre prosaica. A memória emerge de um grupo que ela une [...]. (NORA, 2003, p. 09) 
Resenha: Tramas Publicitárias. Narrativas ilustradas de momentos marcantes da publicidade

A experiência de Berta é a memória viva, individual, de um momento histórico, que se ativa em seus pensamentos e em seus sofrimentos, enquanto as lembranças do Nazismo forem vivas nas mentes das suas vítimas, até o momento em que essas lembranças se convertam em história.

No último conto, No Labirinto de Aleph, o título, ao recuperar a primeira letra do alfabeto hebraico, instaura os desafios do novo mundo em construção. A contemporaneidade com suas novidades modalizam os sujeitos criadores/autores, publicitários/escritores, permeados por mensagens diversas individualizadas que se manifestam pelas possibilidades de interação das redes sociais em tecnologias digitais e pelas ações de comunicação em guerrilha que surgem como resposta à crise dos modelos tradicionais das comunicações publicitárias.

As personagens Bin Laden e Mata Hari, codinomes na rede dos autores da obra, mostram uma trama caótica entre ficção e realidade, que coloca a própria construção da obra e do texto em cena como lugar de discussão sobre os novos sentidos da publicidade, frente às novas possibilidades da materialização e do processo criativo em literatura, que hoje pode se confundir com o processo criativo da publicidade.

Os limites entre publicitários e escritores desaparecem no conto, mostrando a possibilidade de simulação contínua da interface criativa entre publicidade e literatura para construção de experiências estéticas infinitas e que nos fazem repensar sobre as possibilidades estéticas da publicidade para além do estímulo ao consumo.

Carrascoza e Christiane Santarelli nos convidam a pensar na interface da literatura - pelas narrativas dos três contos, associada à narrativa visual da publicidade -, as possibilidades de construção de um conhecimento sensível sobre a experiência vivida no mundo. Fica aqui registrado o convite aos interessados na temática para a possibilidade de uma excelente experiência de leitura.

\section{REFERÊNCIAS BIBLIOGRÁFICAS}

BENJAMIN, W. "Paris a Capital do XIX”. In KOTHE, F.R. (org.). Walter Benjamin. São Paulo: Ática. 1985. Col. Grandes Cientistas Sociais. . Charles Baudelaire: um lírico no auge do capitalismo. Obras escolhidas. V. III, 2ed. São Paulo: Brasiliense, 1991. 
Resenha: Tramas Publicitárias. Narrativas ilustradas de momentos marcantes da publicidade

de Eneus Trindade Barreto Filho

COMPAGNON. A. O demônio da teoria. Literatura e senso comum. Belo Horizonte:

Ed. UFMG. 2003.

MAINGUENAU, D. Novas tendências em Análise de discurso. Campinas. Pontes/UNICAMP. 1989. P.111-116.

NORA, P. Entre História e memória, a problemática dos lugares.Projeto História São Paulo. In Revista do Programa de Pós-Graduação em História. São Paulo: PUCSP. n.10. dez. 1993. p.09.

SIMMEL, G. Philosophie de la modernité. Paris: Payot. 2004. 